\title{
Erratum to: Internet addiction, sleep and health-related life quality among obese individuals: a comparison study of the growing problems in adolescent health
}

\author{
Kayi Eliacik ${ }^{1,8}$ - Nurullah Bolat ${ }^{2}$ - Cemil Koçyiğit ${ }^{3}$ Ali Kanik ${ }^{4}$ Ellen Selkie ${ }^{5}$. \\ Huseyin Yilmaz ${ }^{6} \cdot$ Gonul Catli $^{3} \cdot$ Nihal Olgac Dundar ${ }^{7} \cdot$ Bumin Nuri Dundar $^{3}$
}

Published online: 9 November 2016

(c) Springer International Publishing Switzerland 2016

\section{Erratum to: Eat Weight Disord DOI 10.1007/s40519-016-0327-z}

Unfortunately, under the heading "Internet use", a sentence was wrongly published in the original publication of this article. The complete corrected sentence is given below:

\section{Internet use}

Participants completed a survey which was developed for another study to evaluate the Internet access, device use, Internet and other media usage time, and Internet usage types [31].

The online version of the original article can be found under doi:10.1007/s40519-016-0327-z.

Kayi Eliacik

kayieliacik@gmail.com

Nurullah Bolat

nurullahbolat@yahoo.com

Cemil Koçyiğit

dr.cmlkcygt@gmail.com

Ali Kanik

dralikanik@hotmail.com

Ellen Selkie

eselkie@med.umich.edu

Huseyin Yilmaz

hasanhuseyinyilmaz@windowslive.com

Gonul Catli

gonulcatli@gmail.com

Nihal Olgac Dundar

nodundar@gmail.com

Bumin Nuri Dundar

bumindundar@gmail.com
Also, the references [31] and [32] were wrongly swapped in the earlier publication and same is corrected now. The complete correct order of references is given below:

31. Cavdar S, Sumer EC, Eliacikk K et al (2016) Health behaviors in high school students in Izmir, Turkey. Turk Pediatri Ars 51:22-34. doi:10.5152/TurkPedia triArs.2016.3389

32. Odaci H, Kalkan M (2010) Problematic Internet use, loneliness and dating anxiety among young adult university students. Comput Educ 55:1091-1197. doi:10.1016/j.compedu.2010.05.006

The original version is also updated.

1 Division of Adolescent Medicine, Tepecik Training and Research Hospital, Izmir, Turkey

2 Department of Child and Adolescent Psychiatry, Izmir Tepecik Training and Research Hospital, Izmir, Turkey

3 Department of Pediatric Endocrinology, Izmir Katip Celebi University School of Medicine, Izmir, Turkey

4 Department of Pediatrics, Izmir Tepecik Training and Research Hospital, Izmir, Turkey

5 Division of Adolescent Medicine, MPH, University of Michigan, C.S. Mott Children's Hospital, Ann Arbor, MI, USA

6 Department of Pediatrics, Izmir Katip Celebi University School of Medicine, Izmir, Turkey

7 Department of Pediatric Neurology, Izmir Katip Celebi University School of Medicine, Izmir, Turkey

8 Department of Pediatrics, Division of Adolescent Medicine, Tepecik Training and Research Hospital, Izmir, Yenisehir, Turkey 